УДК 327

DOI 10.30970/vir.2018.45.0.9454

\title{
HYBRIDITY OF CONTEMPORARY THREATS
}

\author{
Piotr Krzykowski \\ Akademia Sztuki Wojennej, \\ al. Gen. Chruściela 103a, Warszawa, Poland, 00-910, tel. +48-22-261813 364, \\ e-mail:p.krzykowski@akademia.mil.pl
}

The world we are dealing with today has made security issues one of the most important matters in the modern world and world of the future. Due to the evolution of thinking about safety, but also because of the often common perception of these problems, these issues have not always been properly interpreted.

Today, the security environment is heteronomous in relation to the surroundings, time and actors at the international security scene. In this respect, particular attention needs to be paid to security threats and their perception by political scene entities. Dynamic changes that have taken place in the world mean that knowledge of the modern security environment will quickly become outdated.

The aim of the article is to present contemporary threats bearing the hallmarks of hybridity, affecting international security, as well as state security. It attempts to explain what hybridity is and how to define hybrid actions, phases of hybrid actions and the impact of hybrid actions on PEMSII areas. The first part of the article presents the contemporary dimension of safety and the characteristics of hybrid actions. It seeks to formulate a new analytical approach to armed conflicts in the context of contemporary security challenges, including their asymmetry, cultural divisions and side effects of globalisation. The second part of the article presents the areas and phases of hybrid actions, the implications of understanding hybrid challenges, opportunities and threats resulting from the changes taking place in the global security environment.

Key words: hybrid threats; international security; hybrid war.

\section{Introduction}

The faces of the «new threats $[6$, p. $54 ; 7$, p. 28$]$ of the 21 st century» that we are witnessing give rise to profound reflection among experts and analysts on the means, methods and instruments for ensuring the security of state in the modern world. Today's security environment is characterised by the blurring of the boundaries between its internal and external dimensions, military and non-military. A comprehensive approach to security should therefore not only cover military threats, but should also account for its entire spectrum.

When considering potential threats to the state security system in the geopolitical environment, it is necessary to pay attention to the diversity of threats and the complexity of problems related to prevention and mitigation of effects in the event of their occurrence. A characteristic feature of the contemporary world of politics is its variability, which affects all the phenomena around us.

(C) Krzykowski Piotr, 2018 
The British General Rupert Smith ${ }^{1}$ said that «...confrontation, conflict, struggle these are the phenomena taking place all over the world, especially (but not only) in Iraq, Afghanistan, the Democratic Republic of Congo and in the Palestinian territories, the states still maintain the armies, treating them as a symbol of their power. But the war that most civilians imagine - the battle fought with people and equipment, or the final forcible settlement of an international dispute - does not exist anymore» [15, p. 21]. However, challenges and threats of a military nature still exist, especially in conflicts of so-called national or territorial origin. Because, if not without these armed formations, there could be any attempt to win or to shift the line of influence to its advantage.

\section{The modern dimension of security}

The state of state security is a reflection of the complex structure of a country's functioning in the geopolitical environment. The progressing globalisation, and at the same time new trends, events, processes that determine the creation of a new kind of phenomena, by transforming and, in a way, «improving» those that we already know from history. They can be conducted in political, economic, military and social environments, including national, ethnic and religious minorities [2, p. 52]. The dynamics of the situation in the strategic security environment is currently determined by the high dependence of many factors, which significantly affects the uncertainty and unpredictability of many situations [16, p. 20]. The development of civilisation entails changes in the way we perceive threats.

Threats resulting from globalisation have created conditions for new actors, which may be both state participants and non-governmental organisations, transnational corporations with dispersed, anonymous ownership and non-state actors, because they play in the «global» space - supra-state or transnational [13, p. 94].

Multidimensionality and complexity of factors influencing constant changes in the strategic security environment, dictated by political, economic, social and information factors, are the source of threats to national security. As a result of these changes, it has become possible to take advantage of the complex connections between the political and economic worlds, as well as social and political problems with the various determinants of individual countries. As a result, these changes may threaten global stability and result in instability in certain countries. Countries are currently fighting a «battle», using mainly money, natural resources, diplomacy and propaganda instead of the armed forces. In order to achieve their objectives, they are able to exert pressure on other states by deliberately misinforming them as to their intentions.

The analysis of the current geopolitical situation and the identification of new threats in the security environment allow for a better understanding of future challenges for national security on a global and regional scale. Security considered in such a manner is interpreted as «...the theory and practice of ensuring that a given entity can survive (exist) and pursue its own interests, in particular by taking advantage of opportunities (favourable circumstances), taking up challenges,

\footnotetext{
${ }^{1}$ Rupert Smith - British General, Commander of the 1991 Gulf War Armoured Division, Commander of the 1995 UNPROFOR Bosnia Force, Commander of the 1996-1998 Northern Ireland Forces, NATO's Deputy Supreme Allied Commander Europe (DSACEUR) in years 1998-2001
} 
Piotr Krzykowski

reducing risks and counteracting (preventing and opposing) all kinds of threats to an entity and its interests...» [1, p. 247].

Considering the above, it should be considered that the notion of security refers not only to an entity such as the state, but also to non-state actors [18, p. 2]. It is about safeguarding vital interests in the economic, political, military, social, environmental and information spheres, but it is also about protecting national sovereignty and territorial integrity. Therefore, the basic aim of each entity (state) should be to strive for proper thinking about the future, and thus functioning in the security environment to safeguard the values which are subject to special protection, as well as to strengthen the military and economic condition of the state, and the efficiency of public administration, which allows the adopted values to be protected and to shield an entity against threats, damages and evil [20, p. 935-953]. It is therefore right to presume that the established (specific) level and area of threat should be recognised as an awareness of the level and quality of safety.

While attempting to explain the influence of hybridity of contemporary threats on the security of state, one cannot ignore its connections with the already indicated phenomenon (event, situation) of threat. This is because it is at the same time a premise (indication) that the lack of a threat creates an important aspect of safety. The understanding of the term «threat» therefore means a certain psychological or conscious state caused by the perception of phenomena that are subjectively assessed as unfavourable or dangerous, and on the other hand it implies objective factors causing states of uncertainty and concern [6, p. 54]. Therefore, the concept of a «threat» is within the sphere of consciousness of every citizen and is subjective in nature. Thus the ability to counteract, methods of securing and prevent against threats and their complex nature will only become possible if safety is managed effectively. In creating the architecture of security environment of a given entity, its improved and more peaceful future, it should be (security) considered in a systemic way.

This makes it important to be aware of the danger (challenges) that exists (exist) as a phenomenon (event, problem, situation) and have a negative impact on an entity. Therefore, since security is, among other things, both an objective and a subjective state, which has already been mentioned, and threats are a collection of already determined aspects, but also a part of the challenges, assuming negative values, which may continue to occur in the future, therefore, to some extent, we can find a relation between security and threats. However, when analysing these relationships, i.e. the relationship between the state of safety and the state of danger, it can be concluded that this is most often a linear relationship (Fig. 1.). Therefore, by attempting to present this relationship in a linear manner, we can say that it is inversely proportional to the threats that affect the basis, course and/or results of our actions. However, it should be remembered that, as Magnusson put it, «there is no such thing as an isolated human being or a situation. There is only a relationship between man and the environment. A relationship the meaning of which is reflected in the word threat» $[14$, p. 31].

However, it is assessed that this identification of the relationship between security and emergency is a simplification of its understanding, but also a logical and simple 
way of demonstrating the relationship between threats and security (of the entities) in a strategic but also regional security environment.

Fig. 1: Relationship between the states of safety and emergency

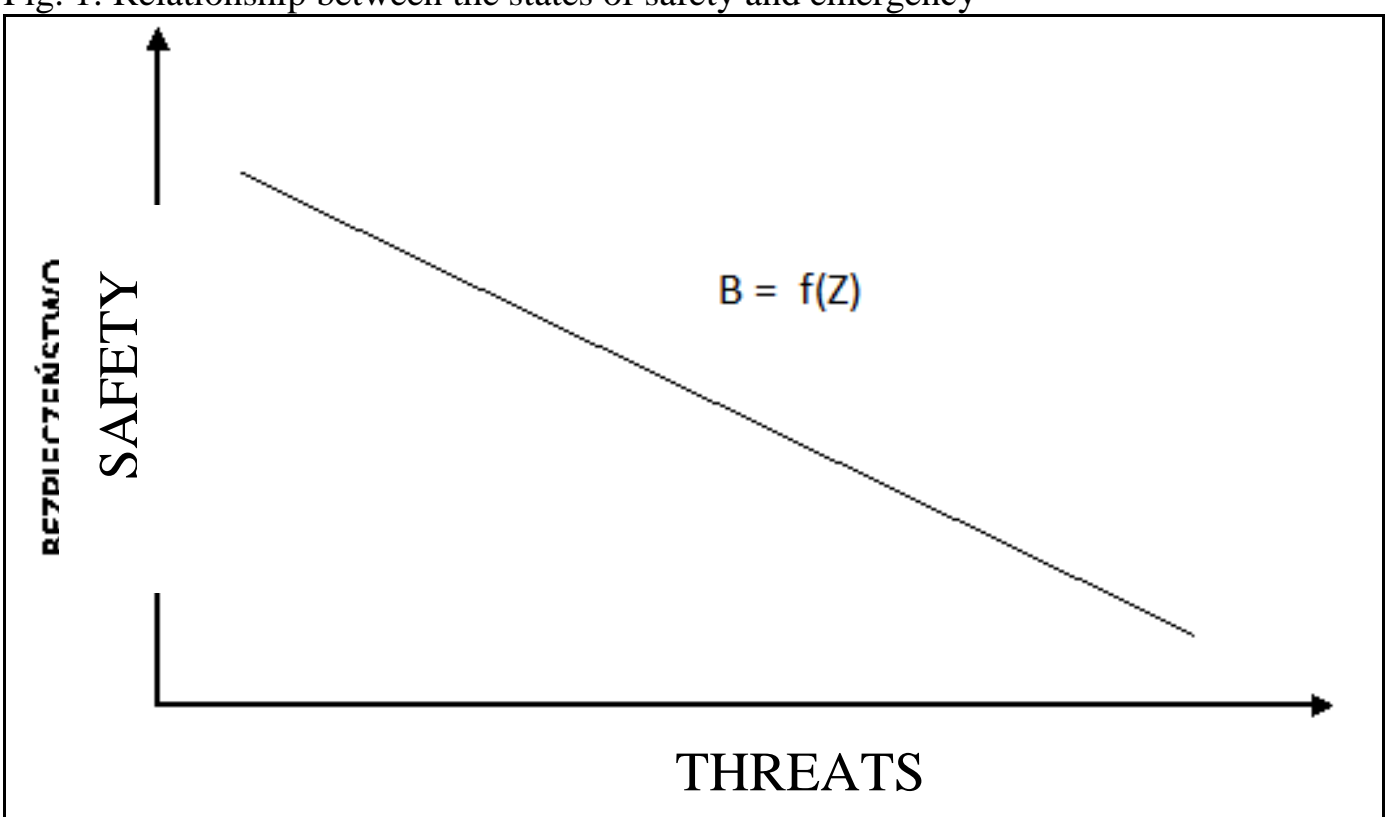

Source: own study [in:] P. Krzykowski, Środowisko bezpieczeństwa globalnego a bezpieczeństwa obywatela, [in:] Bezpieczeństwo personalne wobec współczesnych zagrożeń $i$ wyzwań, ed. Drabik K., Żyła M., Wydawnictwo ASzWoj, Warszawa 2017, ISBN 978-83-7523-582-1, p. 228.

It should be noted that the mere perception of threats, especially external ones, by a given entity may be a reflection of the real state of affairs, but it may also be false. Daniel Frei (Swiss political expert), among others, tried to explain the nature of security in a model way by indicating four states. [19, p. 4-5]:

1. a state of insecurity where there is a large, genuine external threat and the perception of that threat is correct;

2. a state of obsession, where a negligible threat is perceived as high;

3. a state of false security occurs when an external threat is serious and perceived to be minor;

4. a state of safety occurs when an external threat is negligible and the perception is correct.

Analysing the phenomena, events and processes taking place in the contemporary security environment through the processes shaping and creating an international (global, regional, local) security system, we can distinguish two aspects of it, namely:

- safety understood as the resistance to dangerous situations (threats), with attention focused on the safety unreliability of an object, i.e. its susceptibility to dangerous situations; 
- system security understood as its ability to protect internal values against external and internal threats [14, p. 31].

Therefore, according to some scientists, the very nature of international security is usually defined by a set of features which are considered to be common in the context of an international security environment, as they describe the relations between the entities constituting the international community [5, p. 19]. This is the case regardless of the security context of an entity: regional, sub-regional, local. For these reasons, it can be assumed that research in the area of international security, based on its paradigm, may lead, inter alia, to

a) adopting a permanent security environment based on the paradigm of international reality traits, security environment (anarchy of security environment, safety and vulnerability of entities, evolution of threats, normativity and institutionalisation of entities' safety);

b) defining the course of actions defining security of an entity (e.g. abolishing aggressive war and arms control, international terrorism and many others, both mentioned and not mentioned in the text);

c) joint or separate examination of the following security planes (spheres, dimensions): political, economic, socio-cultural, military [5, p. 23].

Therefore, when considering potential threats to the security system in the geopolitical environment, attention should be paid to the diversity of threats and the complexity of the issues related to prevention and mitigation of effects in case of their occurrence. Today's security environment is characterised by the blurring of the boundaries between its internal and external dimensions, military and non-military. Therefore, a comprehensive approach to security issues covers not only military threats but also their whole spectrum.

\section{What is the hybridity}

Globalisation and increasing interdependence often result in unpredictability of phenomena that are no longer constrained by geographical, political and economic barriers. However, challenges and threats of a military nature still exist, especially in conflicts of so-called national or territorial origin. It should be noted that some countries want to dominate the international arena and the growing economic gap between developed and developing countries may lead to inequalities between them. Uneven economic development of countries, as well as military activities in the areas of armed conflict, may result, among other things, in social conflicts and an increase in uncontrolled migration, which may result in an increase in social tensions. Tensions can also be exacerbated by influencing the media and help of the media creating new needs, consumption models, lifestyles, and even social behaviour and political preferences.

Nowadays, information and its message play a huge role, not only in the formation of a new generation of society, but also in conflicts. Technical novelties and mass media gave rise to the creation of new, much more effective and, consequently, more dangerous propaganda tools. This determines the possibility of using propaganda much more efficiently than ever before in order to use ideological, ethnic and religious tendencies to influence the emotions of the participants in the conflict. Therefore, the 
heterogeneity of the contemporary world has a fundamental impact on «the ways of resolving disputes and conflicts» $[9$, p. 358].

The analysis of literature allows us to conclude that contemporary conflicts based on hybridization are a combination of traditional threats and types of fighting against new phenomena, such as terrorism, cyber-terrorism and the use of the latest technologies, not only on the classical battlefield, but also to achieve the goals of psychological, propaganda and ideological warfare (Fig. 2.).

The battle is fought on many levels. The classic understanding of warfare is accompanied by variations of conflicts based on cyber or psychological solutions, and the success of warfare is determined by the ability to adapt to the situation and coordinate multidimensional actions $[3$, p. 11]. Moreover, the character of contemporary wars determines their dynamics and unpredictability, because «the hybrid nature of conflict can reveal itself with all its power (at any moment of its existence), changing the potential of forces and means applied by parties to the conflict and modifying strategic goals and operational and tactical tasks» $[3$, p. 15$16]$.

Figure 2: Scope of hybrid conflicts

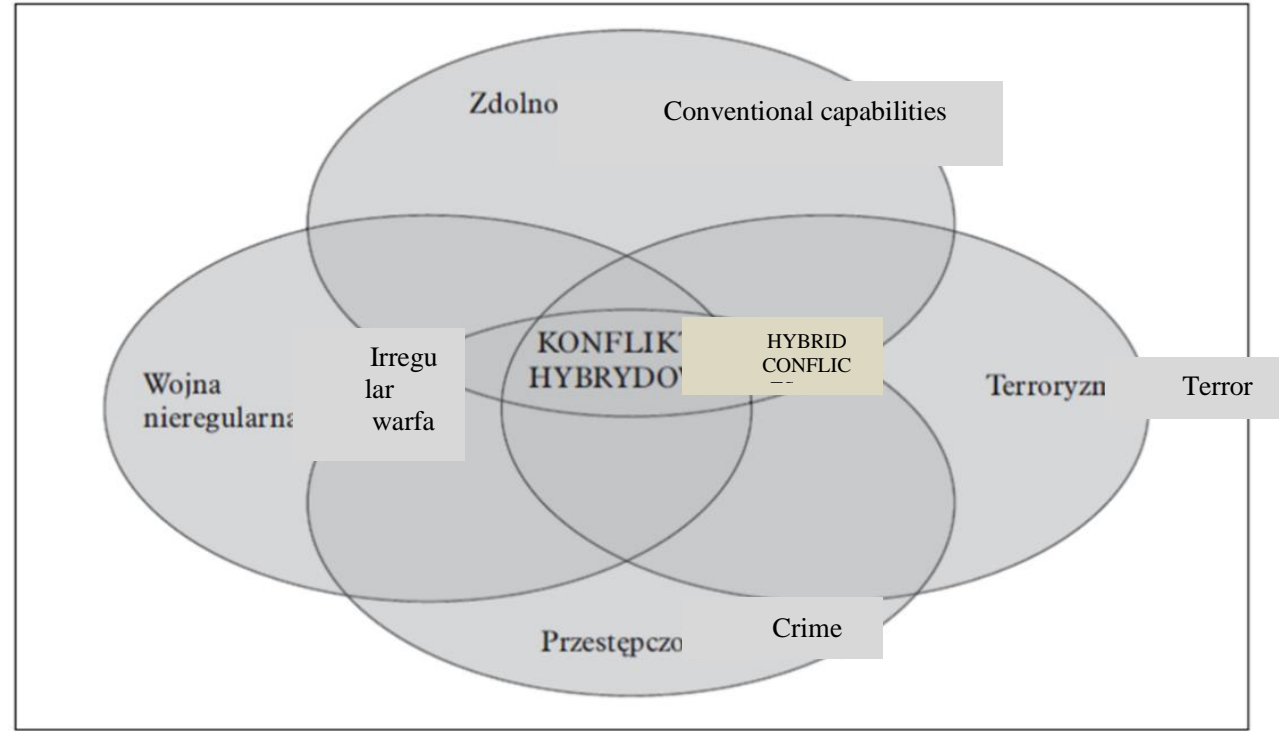

Source: F.G. Hoffman, The (Re) Emergence of Hybrid Threats, presented for the Marine Corps Warfighting Laboratory, MCB Quantico, May 2009, [after:] M.A. Piotrowski, Konflikt nigdy nie jest prosty: amerykańska teoria i doktryna wojen oraz przeciwników hybrydowych, «Sprawy Międzynarodowe», no. 2 (LXVIII)/2015, p. 34.

At the same time, the hybridisation of contemporary threats is contributing to the formulation of a new analytical approach to conflicts in the context of modern security issues, including their asymmetry, cultural divisions and side effects of globalisation. But is this really a new and an unprecedented phenomenon? Is there a need to change the perception of contemporary threats and consequently conflicts? 
Military historians agree that in the past, we already had situations in which many aspects were characteristic of today's hybrid operations [10]. However, «hybrid actions» gained worldwide recognition owing to analysts and military staff as early as at the turn of the 20th and 21st century. Among them, William J. Nemeth, Frank G. Hoffman and Valery Gerasimov deserve special attention. It was William J. Nemeth who first used the concepts of «hybrid operations» and «hybrid war» in 2002 when developing the work Future War of Chechnya: A case of hybrid warfare [17]. Whereas, Frank G. Hoffman's analyses and reflections defined the simultaneous coexistence of a state of war and peace, as well as the disappearance of the border between combatants and civilians and the loss of state monopoly on violence, which is connected with the emergence of non-state entities as a party engaged in fighting [5, p. 18-19].

Valery Gerasimov, on the other hand, in his article Ценность науки в предвидении [22] (The meaning of science in anticipation) never uses the term «hybrid war». However, when analysing the directions indicated by him for the evolution of future wars, there can be no doubt that he talks about the elements characteristic for this phenomenon. Wars will not be preceded by a formal act of their declaration, as it was the case before. They will follow a previously unknown pattern. As an example of a new type of conflict, Gerasimov points to events in North Africa and the Middle East called the «Arab Spring». In his opinion, the «rules of warfare» have changed. Non-military means of warfare have become most important. It is increasingly important to use a variety of political, economic and humanitarian instruments in combination with manipulating the moods of the populations living in the conflict area. These activities are supported by military measures, particularly those of information warfare character and the operations of special units.

\section{How to define hybrid actions}

Progressive globalisation, technological development, evolution in cyberspace, blurring of national borders and creation of non-state entities with high income allowing to create their own policies or to support their implementation by selected state entities - these activities boil down to taking advantage of the opportunity, created by favourable business, legal and political conditions, to implement long-term activities aimed at achieving the intended strategic objectives.

The hybridity of conflicts entails complexity and multidimensionality of activities. No declaration of war, no state of emergency or martial law or state crisis introduction make it difficult to use preventive (armed) forces. Conflicts, campaigns, struggles that are intentionally limited and kept by an invader below a reasonably identifiable threshold of open confrontation. The aim of such asymmetrical, unconventional aggression is to achieve the adopted goals while, at the same time, causing difficulties in making uniform decisions at a national. Under certain circumstances, a single threat may trigger another type of threat, which will have a significant impact on other areas, thus transforming into a hybrid threat. It should be stressed that the greatest threat to state security is posed by unidentified and previously unknown threats, which are characterised by surprise, unconventional actions and asymmetry. Particular attention should be paid to threats generated directly by an invader who does not have its own 
state, state administration or society, and therefore cannot be an entity complying with international law. Pursuing its goals, such an aggressor will use all the tools that are in its resources and are in its opinion capable of ensuring the achievement of its goals. One of the most frequently used hybrid action environments, social media, is used for cheap and quick recruitment of radicals and groups susceptible to manipulation. These can be applied by various state entities, corporations, groups, including terrorist organisations. Cyber terrorism, which can disrupt and prevent the proper functioning of a vulnerable country, can be a particularly dangerous threat to critical infrastructure of a state. The possibility of causing e.g. environmental catastrophes through biological, chemical or radiation contamination of the natural environment (poisoning of water intakes, food, etc.), attacks on information and communication systems (cyber terrorism, cyber attack), use of autonomous platforms, cross-border migrations must be taken into account. When carrying such activities other aspects and limitations, like humanitarian law, international conventions, morality, etc., are neglected.

The analysis of the literature shows that hybrid actions are the activities associated with complexity and multidimensionality. Aiming to achieve political and strategic objectives with the possibility of maintaining the existing economic and diplomatic relations. These activities are carried out by state entities, including non-state entities, in a planned and coordinated manner and combine different means of pressure and dependence on a potential aggressor. They may be conducted in political, economic, military and social environments, including national, ethnic and religious minorities [2, p. 52].

\section{Areas and phases of hybrid operations}

Quite often in the literature one can find a statement that the war between Russia and Ukraine is a classic hybrid conflict. Although none of the analysts explicitly stated this, the adopted method of the invader's influence on the structures of the entity (state) does not allow to doubt that such activities have indeed been carried out. It is the strategy of actions applied that made it possible to achieve the objectives using the available potential, taking into account the changes and trends in the environment. Depending on phase of the plan, it was implemented in a hidden or open manner, using non-military and military instruments.

Such a model of actions, limited by the capabilities and will of the attacking party, occurs in all or in selected areas of impact. The above-mentioned V. Gerasimov distinguishes six phases: latent activities, intensification, initiation of conflictsignalling activities, crisis, resolution, peace restoration [21].

A team of specialists from the Doctrine and Training Centre of the Polish Armed Forces, creating the national concept ${ }^{2}$ of the Analytical Model for Hybrid Assessment

\footnotetext{
${ }^{2}$ Works on the concept were carried out by the project team of the Doctrine and Training Centre of the Polish Armed Forces in close cooperation with a group of domestic and foreign experts. This work is also being developed as part of the Multinational Capability Development Campaign (MCDC). The conceptual scope of the definition and phases of hybrid actions was agreed within the framework of works carried out by the working group for concept development in the sphere of participation of the Polish Armed Forces in countering hybrid threats on 16 September 2015 in Bydgoszcz.
} 
Piotr Krzykowski

of Contemporary Conflicts, segmented the environment and described the course of possible threats in the following areas: political, economic, social, military, infrastructure and information (PEMSII). At the same time, harmonisation of the terminology vocabulary in the area of hybrid activities allowed for the development of phases in hybrid operations. The following phases of hybrid actions were distinguished (Fig. 3.): preparation; destabilisation; military actions; resolution.

Figure 3: Phases of hybrid actions

\begin{tabular}{|c|c|c|c|c|}
\hline \multicolumn{2}{|c|}{$\begin{array}{l}\text { Phase I } \\
\text { Preparation }\end{array}$} & $\begin{array}{c}\text { Phase II } \\
\text { Destabilisation }\end{array}$ & $\begin{array}{c}\text { Phase III } \\
\text { Military Actions }\end{array}$ & $\begin{array}{l}\text { Phase IV } \\
\text { Resolution }\end{array}$ \\
\hline $\begin{array}{l}\text { Latent } \\
\text { part }\end{array}$ & Open part & & & \\
\hline $\begin{array}{l}\text { Actions of } \\
\text { latent } \\
\text { character } \\
\text { by } \\
\text { supporting } \\
\text { and use of } \\
\text { various } \\
\text { forms of } \\
\text { pressure } \\
\text { and } \\
\text { influence. } \\
\text { Key phase } \\
\text { for } \\
\text { preparation } \\
\text { and } \\
\text { execution } \\
\text { of further } \\
\text { actions }\end{array}$ & $\begin{array}{l}\text { Occurs when } \\
\text { symptoms of } \\
\text { hybrid } \\
\text { actions } \\
\text { become } \\
\text { apparent. } \\
\text { Emergence } \\
\text { of } \\
\text { atmosphere } \\
\text { conductive } \\
\text { to } \\
\text { continuation } \\
\text { of achieving } \\
\text { goals, both } \\
\text { on domestic } \\
\text { and } \\
\text { international } \\
\text { scale. }\end{array}$ & $\begin{array}{l}\text { Disruption of } \\
\text { functioning in } \\
\text { centres of power, } \\
\text { safety structures } \\
\text { with the use of } \\
\text { informational } \\
\text { environment in } \\
\text { all or selected } \\
\text { areas, } \\
\text { political, } \\
\text { economic and } \\
\text { social. This phase } \\
\text { may be the goal } \\
\text { itself or include } \\
\text { achieving } \\
\text { other, of } \\
\text { intermediary } \\
\text { goals }\end{array}$ & $\begin{array}{l}\text { Use and support } \\
\text { of paramilitary } \\
\text { groups and/or } \\
\text { regular armed } \\
\text { forces. This } \\
\text { activity is } \\
\text { accompanied by } \\
\text { non-military } \\
\text { actions, including } \\
\text { the diplomatic and } \\
\text { informational } \\
\text { ones }\end{array}$ & $\begin{array}{l}\text { Acceptance } \\
\text { of the } \\
\text { emergent } \\
\text { political } \\
\text { situation }\end{array}$ \\
\hline
\end{tabular}

Source: own study based on: Pawlak C., Konflikt na Wschodzie Ukrainy i aneksja Krymu - Standardowym przykładem działań hybrydowych. Rocznik Bezpieczeństwa Międzynarodowego 2017, vol. 11, no. 1.

The phases of action listed above do not characterise all possible actions taken by a potential opponent. To achieve its objectives, a potential aggressor will use different tools (terrorism, crime, anarchy, etc.) depending on the objectives and identified PEMSII areas of an entity concerned, in particular in the most vulnerable areas.

The activities carried out so far in the eastern Ukraine allow us to conclude that the social and economic area is the greatest and the most serious threat. It is the universality of these activities that allows a single threat form one PEMSII area to influence or penetrate through to the others and to be an impulse triggering escalation, 
e.g. simultaneously in social and economic areas. Additionally supported by a targeted stream of information, not necessarily true ones, it is thus causing fragmentation of the society or internal anxiety. As a result, a hybrid threat will arise in the latent phase, ending up in favourable conflict resolution.

Nowadays, the most noticeable and identifiable action of an aggressor can be seen in the area of information and cyberspace. Information activities will focus on: manipulating and contesting the message, attacking the sequence of logical thinking, creating attitudes and the so-called playing on emotions through an appropriate narrative spin on the reported facts. Therefore, it is a mistake of most analysts and experts to see such threats mainly in external threats to state security instead of the internal ones. Since, this is the point where a threat emerges. It should be borne in mind that a potential opponent with a wide range of possible tools to use, knowing the most vulnerable areas, will apply them in the most unpredictable way, and the scenario of actions once taken will be modified and redirected to different areas depending on their resilience and undertaken countermeasures. In order to be successful in achieving the long-term objectives of a hybrid action, it is essential that it meets certain conditions for the resilience of the area concerned. Today, there is no need to leave home, have strong armed armies or a rich arsenal. Today, the Internet and a suitable organised group of hackers or employees of a specialised computer «troll» workshop are enough. Tracing such activities is very difficult due to anonymity of creators and impact exerted on many levels in the economic, political, social, informational areas in accordance with law, both national and international.

\section{Conclusion}

As stems from the above, hybridity is, in a simplified way, a complex and multifaceted activity. Lack of war and state of emergency declaration makes it difficult to deploy armed forces in accordance with the rule of law, and thus to elicit an appropriate response of the state. Therefore, hybrid actions are deliberately limited and kept by an invader below the reasonably identifiable threshold of conventional war.

At the same time, it should be stressed that the greatest threat to state security is posed by unidentified and previously unknown threats, involving an element of surprise and characterised by unconventionality and asymmetry. Interrelationships of particular threats, penetration to subsequent areas on the basis of cause and effect will cause escalation of threats. This indicates that the hybridity of contemporary conflicts should be seen as the entirety (set) of all actions taken by a potential annexationist in PEMSII areas. According to established patterns, counteracting these phenomena is not the domain of the armed forces themselves or of the non-military system.

Hybridisation of contemporary threats also contributes to formulating a new analytical approach to conflicts in the context of contemporary security problems in the era of globalisation. The above findings and conclusions are the basis for stating that the identified risks should be systematically analysed and monitored. 


\section{REFERENCES}

1. Biała Księga Bezpieczeństwa Narodowego Rzeczypospolitej Polskiej, BBN, Warszawa 2013.

2. Dębczak A., Pawlak C., Keplin J., Analityczny model oceny hybrydowości wspótczesnych konfliktów, «Zeszyty Naukowe AON» 2015, nr 2/(99).

3. Gruszczak A., Hybrydowość współczesnych wojen-analiza krytyczna, [w:] Asymetria $i$ Hybrydowość - stare armie wobec nowych konfliktów, (red.) Sokała W., Zapała B., Warszawa 2011.

4. Gryz J., Współczesny paradygmat bezpieczeństwa międzynarodowego, «Rocznik Bezpieczeństwa Międzynarodowego» 2006.

5. Hoffman F.G., Conflict in the 21st century: Rise of the Hybrid Wars, Arlington 2007 [online], http://www.potomacinstitute.org/images/stories/publications/potomac_hybridwar_0108.pdf [dostęp: 28.03.2018]

6. $\quad$ Korycki S., System bezpieczeństwa Polski, Warszawa 1994

7. Kozub M., Myśleć strategicznie o bezpieczeństwie przyszłości, Warszawa 2013.

8. Krzykowski P. Środowisko bezpieczeństwa globalnego a bezpieczeństwa obywatela, [w:] Bezpieczeństwo personalne wobec wspótczesnych zagrożeń $i$ wyzwań, (red.) Drabik K., Żyła M., Warszawa 2017.

9. Malendowski W., Spory i konflikty międzynarodowe, [w:] Międzynarodowe stosunki polityczne, (red.) E. Bosacka, Poznań 1997.

10. Murray W., Mansoor P.R., Hybrid warfare - fighting complex opponents from the ancient world to the present, Cambridge 2012.

11. Pawlak C., Konflikt na Wschodzie Ukrainy i aneksja Krymu - Standardowym przyktadem działań hybrydowych. «Rocznik Bezpieczeństwa Międzynarodowego» 2017, vol. 11, nr 1

12. Piotrowski M.A., Konflikt nigdy nie jest prosty: amerykańska teoria i doktryna wojen oraz przeciwników hybrydowych, «Sprawy Międzynarodowe», 2015, nr 2 (LXVIII),

13. Potulski J., Geopolityka w świecie ponowoczesnym, Instytut Geopolityki, Częstochowa 2010.

14. Sienkiewicz S., Zarzadzanie bezpieczeństwem systemów, [w:] Bezpieczeństwo w administracji $i$ biznesie., (red.) Grzybowski M., Tomaszewski J., Gdynia 2007.

15. Smith R., Przydatność Sity Militarnej. Sztuka wojenna we współczesnym świecie, Polski Instytut Spraw Międzynarodowych, Warszawa 2010.

16. Wiatr M., Między strategia a taktyka, Toruń 1999.

17. William J. Nemeth, Future war of Chechnya: A case of hybryd warfare https://calhoun.nps.edu/bitstream/handle/10945/5865/02Jun_Nemeth.pdf [dostęp: 12.03.2018].

18. Zając J., Zięba R., Opracowanie na temat prognozy (zdefiniowania $i$ gradacji) interesów narodowych i celów strategicznych $w$ dziedzinie bezpieczeństwa $w$ perspektywie 20 lat, www.bbn.gov.pl/ /download. $h p ?$ s=1\&id=646, [dostep: 20.03.2017].

19. Zięba R., Kategoria bezpieczeństwa w nauce o stosunkach międzynarodowych, [w:] Bezpieczeństwo narodowe i międzynarodowe u schytku XX wieku, (red.) Bobrow D. B., Haliżak E., Zięba R., Warszawa 1997.

20. Zięba R., Teoria ogólna bezpieczeństwa państwa $w$ stosunkach międzynarodowych [w:] Stosunki międzynarodowe w XXI wieku, (red.) Haliżak E., Kuźniar R., Michałowska G., Parzymies S., Simonides J., Zięba R., Warszawa 2006.

21. Герасимов В. (2013), Новые вызовы требуют переосмысления форм и способов ведения боевых действий, Военно-Промышленный Курьер, номер 8 (476), 27.02-05.03.2013 года.

22. Герасимов В., Ценность науки в предвидении, «Военно-промышленный курьер» z 27 II 2013 r. [online], http://www.vpk-news.ru/articles/14632, tłumaczenie na języ angielski, https://inmoscowsshadows.wordpress.com/2014/07/06/the-gerasimov-doctrine-and-russian-non-linearwar/ [dostęp: 31.03.2018]. 


\title{
ГІБРИДНІСТЬ СУЧАСНИХ ЗАГРОЗ
}

\author{
Пьотр Кшиковскі \\ Академія військового мистецтва, \\ ал. Генерала Грушеля, 103а, м. Варшава, Польща, 00-910, тел. +48-22-261813 364, \\ e-mail: p.krzykowski@akademia.mil.pl
}

Світ, $з$ яким ми сьогодні маємо справу, зробив питання безпеки одним 3 найважливіших питань у сучасному світі та світі майбутнього. Через еволюцію мислення про безпеку, але також і через часто поширене сприйняття цих проблем, ці питання не завжди вірно інтерпретували.

Сьогодні середовище безпеки є гетерономним по відношенню до оточення, часу та учасників міжнародної системи безпеки. У цьому відношенні особливу увагу необхідно приділяти загрозам безпеки та їх сприйняттю політичними суб'єктами. Динамічні зміни, що відбулися у світі, означають, що знання сучасного середовища безпеки швидко застарівають.

Метою статті є представлення сучасних загроз, які мають ознаки гібридності, що впливають на міжнародну безпеку, а також державну безпеку. Автор намагається пояснити, що таке гібридність і як визначити гібридні дії, фази гібридних дій і вплив гібридних дій на регіони. У першій частині статті представлено сучасний вимір безпеки та характеристики гібридних дій. Сформульовано новий аналітичний підхід до збройних конфліктів у контексті сучасних викликів безпеці, включаючи їх асиметрію, культурні розбіжності та побічні ефекти глобалізації. У другій частині статті представлено напрямки та етапи гібридних дій, наслідки розуміння гібридних викликів, можливостей і загроз, що виникають внаслідок змін, які відбуваються у глобальному середовищі безпеки.

Ключові слова: гібридні загрози; міжнародна безпека; гібридна війна. 